\title{
Biochar, Bentonite and Potassium Humate Effects on Saline Soil Properties and Nitrogen Loss
}

\author{
S. A. Abdeen ${ }^{1^{*}}$ \\ ${ }^{1}$ Soils and Water Department, Faculty of Agriculture, Al-Azhar University, Cairo, Egypt. \\ Author's contribution
}

The sole author designed, analyzed, interpreted and prepared the manuscript.

Article Information

DOI: $10.9734 / A R R B / 2020 / v 35 i 1230310$

Editor(s):

(1) Dr. Olatunde Samuel Dahunsi, Landmark University, Nigeria.

Reviewers:

(1) Budi Hadi Narendra, Forest Research and Development Center, Indonesia. (2) Lawrence O. Amadi, Rivers State University, Nigeria. Complete Peer review History: http://www.sdiarticle4.com/review-history/63007

Original research Article

Received 11 September 2020

Accepted 24 November 2020

Published 11 December 2020

\section{ABSTRACT}

Aim: In order to study the effect of biochar, bentonite and potassium humate on saline soil characteristics, barley growth and nitrogen loss, a column experiment was conducted. Addition of the above mention materials was hypothesized to improve the characteristics of saline soil and decrease nitrogen loss in the leachate solution.

Place and Duration of Study: Farm of Soils and Water Department, Faculty of Agriculture, AlAzhar University, Cairo, Egypt during the winter season of 2019.

Methodology: Biochar and bentonite were added with rates 0,5 and $10 \mathrm{~g}_{\mathrm{kg}}{ }^{-1}$; and the rates of potassium humate were 0,5 and $10 \mathrm{mg} \cdot \mathrm{kg}^{-1}$. Excess irrigations were implemented three times (on 12th, 24th, 36th days) during growing season. Leachate solution was collected after each excess irrigation from each column to determine nitrogen loss.

Results: Main results show that total organic carbon and soil porosity were increased by increasing the addition rates of the studied materials, especially at the high rates of biochar and bentonite. Also, the availability of water significantly increased. Addition of biochar and bentonite gave the highest decreasing in leachate solution volume. Nitrogen loss was decreased significantly at the highest rates of the studied materials, where the decrement percentage in leachate solution reached at $36.07 \%, 35.82$ and 23.81 at the highest rates of biochar, bentonite and potassium humate, respectively. That led to increasing the retention of available nitrogen in saline soil. Fresh and dry weights of barley plants were increased significantly by increasing the addition rates of all amended 
materials. Macronutrients (NPK) content and uptake were increased significantly by increasing the addition rates of the studied materials.

Conclusion: Research results proved that changes in soil properties caused a significant increase in barley growth and nutrients uptake. Addition of biochar and bentonite were the best option for improving saline soil properties, barley growth and nutrients uptake and reduce nitrogen loss by improving nitrogen retention and decreasing the leachate volume.

Keywords: Saline soil; nitrogen retention; biochar; potassium humate; bentonite.

\section{INTRODUCTION}

Soil degradation, that caused by salinity, is seen as a serious problem for agricultural productivity and nutrients availability. Tackling the issue of salinity is therefore very important to achieve food security. Therefore, increasing water use (leaching requirements) in the root area to salinity control and management are essential for tackling salinity problems. But that is lead to loss water and nutrients by leaching especially in sandy soil [1].

Organic carbon and nutrients availability in salt affected soils are influenced by chemical reactions at soil complex and chemical equilibrium among soil solution, adsorbed and precipitated/solid phases. Ions concentration in soil solution due to excess adsorption or excess leaching produces a nutrient deficiency problem [2].

For improving growth and productivity under saline conditions in arid to semi-arid areas, application of organic amendments has shown beneficial effects on growth and yield [3]. N fertilizer may be lost due to nitrate leaching, potentially polluting surface and ground water, or even lost by ammonia gaseous emissions, or through nitrification and denitrification products [4].

[5] reported that the plants take up and use just 20-30 percent of $N$ in fertilizer. Application of mineral $\mathrm{N}$ fertilizer to soils are consider the main source of $\mathrm{NO}_{3}^{-}$pollution [6]. Continuous application of highly rates of mineral fertilizers specially, nitrogen causing a pollution in the soil and also, danger to the broader environment and human health [7].

Biochar is a solid product of thermal decomposition (at temperature of $300-600^{\circ} \mathrm{C}$ ) of various biomass and pyrolysis conditions from different sources in an oxygen-limited environment, and a carbon rich product which is derived from the pyrolysis of organic carbon under limited oxygen conditions [8].
The properties of biochar differ according to the raw materials and pyrolysis conditions, and will have different effects on soils [9]. It has high adsorption performance and it can improve the availability and retention ability of $\mathrm{N}$ and $\mathrm{P}$ in soil [10], and organic carbon, high surface area, highly microporous structure, existence of active organic functional groups, and generally high $\mathrm{CEC}$ and $\mathrm{pH}$, it is used to reduce $\mathrm{CO}_{2}$ emissions and increase farmland soil and crop yields [11]. This may be due to it will take up $\mathrm{N}$ through ion exchange, extract $\mathrm{NH}_{3}{ }^{+}$through adsorption, and induce immobilization with flow on the $\mathrm{NO}_{3}{ }^{-}$ leaching consequences.

Humic substances are readily available and lowcost materials that are used to enhance crop production and reduce nitrogen loss. However, there is little consensus on the efficacy of their components [12]. They have various acidic functional groups, a high specific surface area, high cation exchange ability, and good absorption properties. These characteristics are conducive to simulating plant growth and nutrient uptake, and preserving $\mathrm{NH}_{4}{ }^{+}$of volatilization [13].

Bentonite and potassium humate addition enhanced sandy soil properties which reflected on increased soil fertility and productivity [14]. Bentonite has a high cation capacity which increase soil water content [15] and would be expected to have high nutrient retention. Use of bentonite may encourage sandy soil aggregates, water retention and increase nutrients [16]. It is a natural clay and has been documented in several countries as good materials to improve soil characteristics and water retention [17].

The risk of nitrogen loss in saline soil through leaching is even higher than normal soil. Hence, improving soil nitrogen retention is the key to reduce nitrogen by leaching loss. There are little studies and lack in attention to study the changes in soil properties and $\mathrm{N}$ loss as a result of addition biochar, bentonite and potassium humate. There is an urgency to improve the characteristics of saline soil and reduce nitrogen 
loss under the conditions of salt- affected soils. So, the target of this research was to examine the effect of biochar, bentonite and potassium humate on saline soil characteristics and nitrogen loss.

\section{MATERIALS AND METHODS}

\subsection{Description of the Investigated Materials}

\subsubsection{Biochar}

Biochar was prepared from a commercial product of wood sawdust from local producer using pyrolysis processes at temperature $\left(300-350^{\circ} \mathrm{C}\right)$. The biochar characteristics are as follows: Total $\mathrm{N}, \mathrm{P}$ and $\mathrm{K}$ were $0.80,0.18$ and $1.20 \%$, respectively, total carbon $49 \%$. Biochar was a soft, alkaline $(\mathrm{pH} 9.45)$ and soluble salinity $(0.60$ dS. $m^{-1}$ )

\subsubsection{Bentonite}

Its powder dark yellow, $\mathrm{pH}$ and $\mathrm{EC}$ values were: 7.22 and 2.95 dS. $\mathrm{m}^{-1}$, respectively. The percentage of $\mathrm{SiO}_{2}, \mathrm{Al}_{2} \mathrm{O}, \mathrm{Fe}_{2} \mathrm{O}_{3}, \mathrm{~K}_{2} \mathrm{O}$ were 24, 55,6 and $1.40 \%$, respectively. It obtained from El-Basatin for industry -Industrial Zone- ElBasatin- Cairo - Egypt.

\subsubsection{Potassium humate (K- humate)}

The potassium humate characteristics are as follows: the percentage of potassium humate was $85 \%$. EC and $\mathrm{pH}$ values were $0.08 \mathrm{dS} . \mathrm{m}^{-1}$ and 8.10 respectively. Total $\mathrm{N}, \mathrm{P}$ and $\mathrm{K}$ were $1.87,0.03$ and $6.50 \%$, respectively. The samples were brought from Agropest control, Alexandria desert road.

\subsubsection{Soil}

Surface samples of loamy sand soil $(0-30 \mathrm{~cm})$ were collected from El- Khatatba, CairoAlexandria, desert road, Menoufiya Governorate. The characteristics of the investigate soil were shown in Table 1.

\subsection{Experimental Design}

The experiment (A column experiment) was designed at the Faculty of Agriculture, Al-Azhar University, Nasr city, Cairo, Egypt to study the effect of biochar, bentonite and potassium humate on $\mathrm{N}$ loss, soil characteristics, barley growth and nutrients uptake under the conditions of saline soils. It was set up in a Randomize Complete Block design with three replicates per treatment. In the beginning, one column was prepared as an individual unit for determined the leaching requirements (LR). Treated materials were ground and sieved $<2 \mathrm{~mm}$. Addition rates were $0,5,10 \mathrm{gkg}^{-1}$ for biochar and bentonite; and 0,5 and $10 \mathrm{mgkg}^{-1}$ for $\mathrm{K}$ - humate. Treated materials were mixed with the soil before planting for 7 days to allow soil stabilized with the studied materials with moisture being maintained by irrigation at $60 \% \mathrm{FC}$.

Plastic columns (cylindrical PVC pots) with an internal diameter of $15 \mathrm{~cm}$ and a depth of $45 \mathrm{~cm}$ were used. The columns have a small hole to allow drainage excess water, each column filled with $7 \mathrm{~kg}$ of amended soil with the studied materials. A layer of coarse sand was used at the bottom of each column to prevent soil from entering with the leachate. Total amount of applied water were14.25 liter (9.25liter for irrigation at FC +5 liter for leaching) during the experimental period. The leaching requirements were added only three times. First, the water added to the soil until reaching saturation capacity, then the leaching requirements were added. Excess irrigations were implemented three times (on $12^{\text {th }}, 24^{\text {th }}, 36^{\text {th }}$ days) during growing season. Water was added frequently in small quantities to avoid water flowing down along the inner wall of column. Leachate solution was collected after each excess irrigation from each column to determine nitrogen loss.

Ten seeds of barley (Hordeum vulgare) were cultivated in every column, and thinned to 5 plants after 10 days. Mineral fertilizers were applied according to the recommended dose of the Ministry of Agriculture. Nitrogen fertilizer rate was split into three doses as ammonium nitrate $(33.5 \% \mathrm{~N})$ at rate of $358 \mathrm{~kg} \mathrm{fed}^{-1}$; the first dose $(20 \%)$ at sowing, the second dose $(40 \%)$ after 25 days from sowing and the third dose $(40 \%)$ after 50 days from sowing. Super phosphate 15\% $\mathrm{P}_{2} \mathrm{O}_{5} \quad\left(200 \mathrm{~kg} \cdot \mathrm{fed}^{-1}\right)$ was added during soil preparation and potassium sulfate $48 \% \mathrm{~K}_{2} \mathrm{O}(50$ $\left.\mathrm{kg} . \mathrm{fed}^{-1}\right)$. After the experimental period (60 days) barley shoots of each treatment were cut just one $\mathrm{cm}$ above soil surface and washed, fresh and dry weight were recording. The dried plant tissues were ground using a mill and kept for plant analysis. Soil samples were collected from each pot after harvesting, air- dried, crushed and passed through a 2-mm sieve and kept for soil analysis. 


\subsection{Soil and Plant Analysis}

The particle size distribution was determined by hydrometer method after dispersion with sodium hexametaphosphate as described by [18]. The bulk density was determined according to [19] and calculated as: Bulk density $=\frac{M(g)}{V(c \mathrm{~cm} 3)}$. Total porosity (assumed particle density ps $=2.65$ $\mathrm{Mg} \cdot \mathrm{m}^{-3}$ ) was calculated from bulk density (Bd), using the equation below: $T P(\%)=\left(1-\frac{B d}{p s}\right) \times$ 100. Soil $\mathrm{pH}$ was determined according to [20]. Cation Exchange Capacity was determined by method described by [21]. Total soluble salts were determined [22]. Total organic carbon was determined by the dichromate wet oxidation method as modified and described by [23]. Exchangeable sodium percentage (ESP) of the soil was calculated using [24] formula as follows: ESP $=\frac{\text { Exchangeable sodium }}{C E C} \times 100 . \quad$ Leaching requirements (LR) were calculated with divided to electrical conductivity in irrigation water $(0.40$ $\mathrm{dS} . \mathrm{m}^{-1}$ ) and electrical conductivity in drainage water $\left(1.1 \mathrm{dS} \cdot \mathrm{m}^{-1}\right)$ as follows: $L R=\frac{E C I W}{E C D W}$. [25]. $W H C \%=\frac{M W-M d}{M d} \times 100$, where $\mathrm{Mw}$ is mass of wet soil at saturated and Md is mass of ovendried soil at $105^{\circ} \mathrm{C}$. Available N, P and $\mathrm{K}$ were extracted by $\mathrm{KCl}(2 \mathrm{M}), \mathrm{NaHCO}_{3}(0.5 \mathrm{M})$ and $\mathrm{CH}_{3} \mathrm{COONH}_{4}(1 \mathrm{M})$, respectively. Total NPK of barley plant were determined by Kjeldhal, spectrophotometer and flame photometer, respectively by using $0.50 \mathrm{~g}$ of dry matter from each sample was digested by a mixture of concentrated perchloric acid and sulfuric acid (1: $3)$. Then, the plant digests were diluted with distilled water to a volume of $50 \mathrm{ml}$ [26].

\subsection{Statistical Analysis}

Differences among means were tested for statistical significance by one-way analysis of variance using SPSS package version 20 . Statistical significance was considered when $\mathrm{P} \leq$ 0.05 according to [27].

\section{RESULTS AND DISCUSSION}

\subsection{Nutrients Retention and N Loss}

Data presented in Table 2 show that $\mathrm{N}$ availability was increased significantly by increasing the addition rates of all studied materials. The highest values of $\mathrm{N}$ were 64,62 and $56.5 \mathrm{mg} \cdot \mathrm{kg}^{-1}$ at the highest rate of biochar, bentonite $\left(10 \mathrm{~g}^{\mathrm{kg}}{ }^{-1}\right)$ and $\mathrm{K}$ - humate $\left(10 \mathrm{mg} \cdot \mathrm{kg}^{-1}\right)$, respectively. The effects of these materials on soil $\mathrm{N}$ leaching are related to their structure. This could be due to more distinct functional groups on their surface that may attract positive ions. [28]. The negatively charged oxygen-containing functional groups on the biochar surface may act as $\mathrm{NH}_{4}{ }^{+}$retention sites, and $\mathrm{NO}_{3}{ }^{-}$can also be adsorbed to these sites indirectly via electrostatic bridge-binding with multivalent metal cations [29]. On the other hand, the decreasing in $\mathrm{N}$ loss was observed as a result addition of the studied materials, where the decrement percentage in leachate solution reached $36.07 \%$ at $10 \mathrm{~g} . \mathrm{kg}^{-1}$ of biochar. That led to increasing the retention of available nitrogen in soil, where the increasing percentage reached at $26.98 \%$. This mainly led to increased plant growth and high $\mathrm{N}$ uptake. Similar data were observed by [30]. Biochar has high adsorption efficiency and can increase nitrogen and phosphorus availability in crops and retain nitrogen and phosphorus in soil. [10]. The retention of $\mathrm{N}$ in soil may be due to the large surface and pores of bentonite and biochar. Similar data were obtained by [31]. Also, [32] attribute that to the ammonium ion space and intermolecular forces that can assist in ammonium ion biochar bonding.

On the other hand, the addition of bentonite, biochar and $\mathrm{K}$ - humate affected on $\mathrm{P}$ and $\mathrm{K}$. In arid soils, biochar can decrease the loss of nitrogen and phosphorus [33]. The highest values of $P$ and $K$ were $16.50 \mathrm{mg} \cdot \mathrm{kg}^{-1}$ and $134.50 \mathrm{mg} \cdot \mathrm{kg}^{-1}$, respectively at 10 ton.fed $^{-1}$ of bentonite. Bentonite have ability to increase water retention and a source of nutrients [16]. It could be noticed that there is a positive attitude between the decreasing in $\mathrm{N}$ leaching and additions of biochar, bentonite, K- potassium, which may be explained by the increasing soil water retention. Bentonite can be used as an alternative source of nutrients and as a means of increasing the soil fertility [34], and reducing soil nitrate-N leaching [35]. Also, [36] suggested that there is a positive correlation between addition of biochar and soil $\mathrm{N}$ retention, this was attributed to adsorption of ammonium by biochar.

\subsection{Effect of Biochar, Bentonite and K- Humate on Soil Leachate Volume}

The data illustrated in Fig.1. ( $a$ and b) show that volume of soil leachate solution during the experimental period as affected by the studied materials. Generally, the leachate volume decreased significantly by increased the addition 
rates. The highest decrement percentage of leachate volume were $37.72 \%$ and $34.74 \%$ and $14.26 \%$ at the highest rates of bentonite, biochar and K-humate, respectively. Biochar is a biomass-rich carbon product that can retain water and nutrients [37]. The decrement in leachate volumes are play an important role in decreasing nitrogen loss via leaching. This is due to its highly porous with a good water retention capacity [17].

\subsection{Soil Properties as Affected by The Investigated Materials}

From data in Table 3 It has been shown that, as a result the addition of biochar, bentonite and $\mathrm{K}$ humate, there is no significant changes in soil $\mathrm{pH}$ and EC values. Generally, $\mathrm{pH}$ values slightly increased by increasing the addition rates of biochar and bentonite. A similar result was observed [30]. While, the values slightly decreased by increasing $\mathrm{K}$ - humate. The humate exchanges $\mathrm{H}^{+}$ions with soil $\mathrm{Na}^{+}$in order to lower the $\mathrm{Na}$ content and increase $\mathrm{H}^{+}$levels, resulting in lower soil $\mathrm{pH}$. The agricultural practices (lechering requirements, addition of the studied materials) during the experimental period led to changes in soil salinity. The values were decreased by addition biochar and K-humate. The lowest value (4.20 dS. $\mathrm{m}^{-1}$ ) was observed at the highest rate $\left(10 \mathrm{mg} \cdot \mathrm{kg}^{-1}\right)$ of $\mathrm{K}$ - humate. This may be referred to the dilution factor, where the biochar and humate absorbed water many times of their weight, which diluted the saline effect [38] obtained that humate absorbed many times their weight of water, which diluted the salt effect and stored it for relatively long period. Additionally [39] discussed the reduction in salinity as a result of the replacement of $\mathrm{Na}$ with $\mathrm{K}$ of the humate. On the contrast, [40] reported that addition of biochar significantly increased soil EC.

Total organic carbon (TOC) increased by increasing the addition rates of the used materials. The values were reached at 3.20, 2.97 and $2.91{\mathrm{~g} . \mathrm{kg}^{-1}}^{-1}$ at the highest rates of biochar, bentonite and K-humate, respectively. Soil organic carbon significantly increased by addition of biochar [40] and [30]. Also, addition of bentonite improved sandy soil chemical properties and fertility [41] and potassium humate acts as organic matter which promote of soil [42]. Total porosity increased and bulk density decreased by increasing the addition rates of the studied materials, especially at biochar treatments. These data are in line with those obtained by [43].
Concerning of field capacity (FC), wilting point (WP) and available water (AW) as affected by the addition materials. It noticed that, the highest rates of the studied materials gave the highest values of soil water constants. The highest values of $\mathrm{FC}$ and WP and AW were $11.90 \%, 4.00 \%$, and $7.90 \%$, respectively. The high porosity of biochar and its large surface area which lead to increase field capacity, thereby reducing the percolation of soil water and thus the transporting dissolved nutrients [44].

\subsection{Plant Growth and Nutrients}

Fresh and dry weights of barley plant are presented in Table 4. The data clear that there is a significant increase in FW and DW in the soil treated with biochar, bentonite and K- humate coincided with the improvement in soil characteristics. Similar trend found by [45]. The highest values of FW and DW were 67.20 and

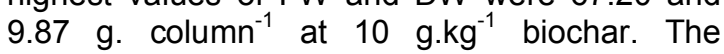
increasing in FW and DW could be attributed to the fact that application of biochar enriched soil with high amount of some nutrients. These findings are in line with [46]. In addition, biochar improves soil water retention, which can in turn favorably affect plant growth [47]. Also, the highest percentage increasing reached $42.07 \%$ and $24.94 \%$ of $\mathrm{FW}$ and DW, respectively at 10 g. $\mathrm{kg}^{-1}$ biochar.

NP and $\mathrm{K}$ content were increased significantly by increasing the addition rates of the studied materials. The highest values of $\mathrm{N}$ content and uptake were $1.75 \%$ and $172.73 \mathrm{mg}$. column $^{-1}$, respectively at the highest rate of biochar $\left(10 \mathrm{~g} \cdot \mathrm{kg}^{-1}\right)$. NPK uptake and biomass increased by increasing the rates of biochar [30].

The highest $P$ content and uptake were $0.38 \%$ and $36.10 \mathrm{mg}$. column ${ }^{-1}$, respectively at $10 \mathrm{~g} \cdot \mathrm{kg}^{-1}$ of bentonite. Total content of $P$ and $K$ were significant increase as a result addition of bentonite and K-humate. This referred to the great function of $\mathrm{K}$ - humate improve the efficiency of nutrients [14]. The highest content of $\mathrm{K} 1.60 \%$ at $10 \mathrm{mg} \cdot \mathrm{kg}^{-1} \mathrm{~K}$ - humate. Potassium humate is a natural material that can improve soil properties and nutrient availability [48]. While, the highest uptake was $153.97 \mathrm{mg}$ column $^{-1}$ at $10 \mathrm{~g} . \mathrm{kg}^{-1}$ of bentonite. Nutrients adsorption by biochar and bentonite is affected by soil properties [10]. 
Table 1. Soil properties of the investigated soil

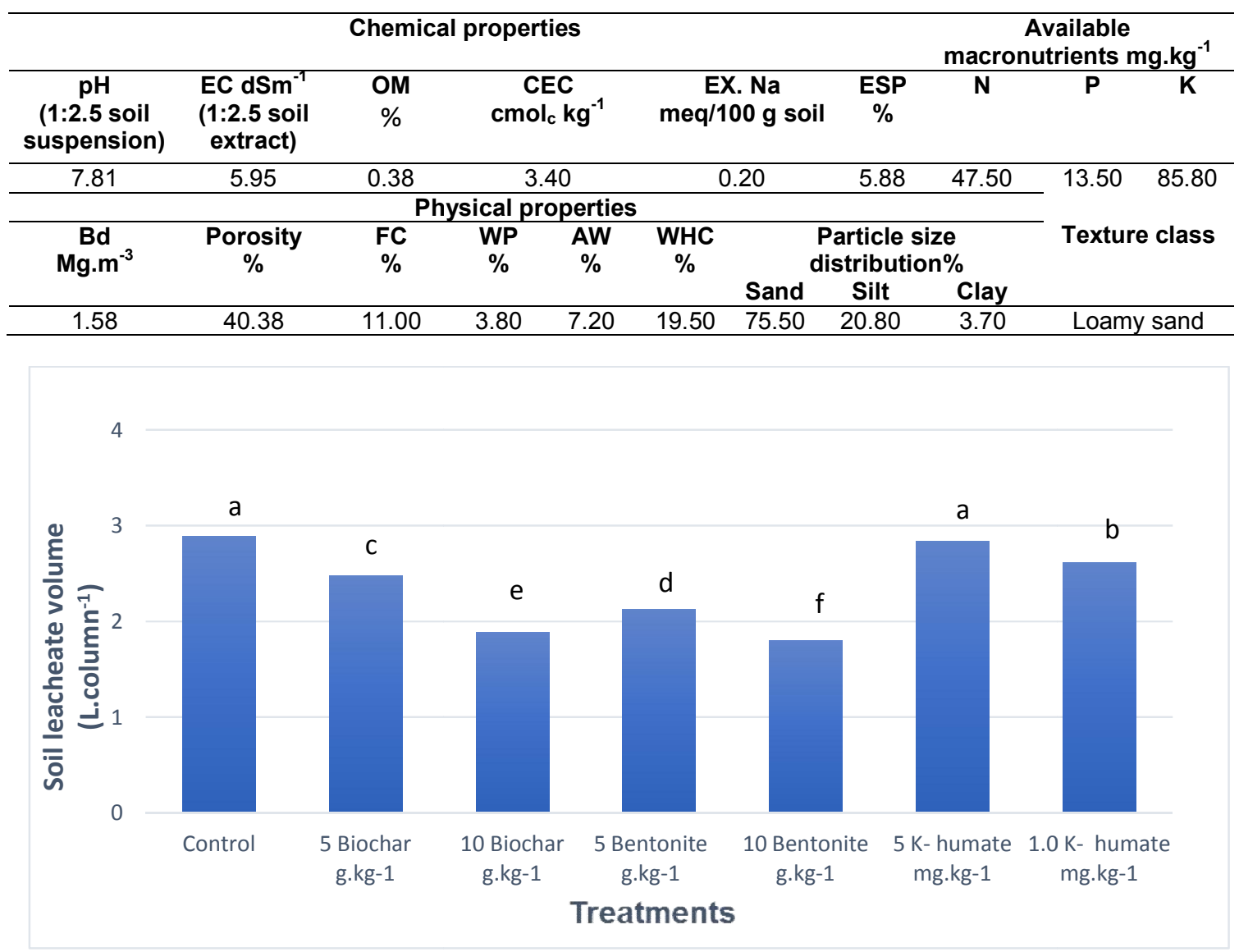

(a)

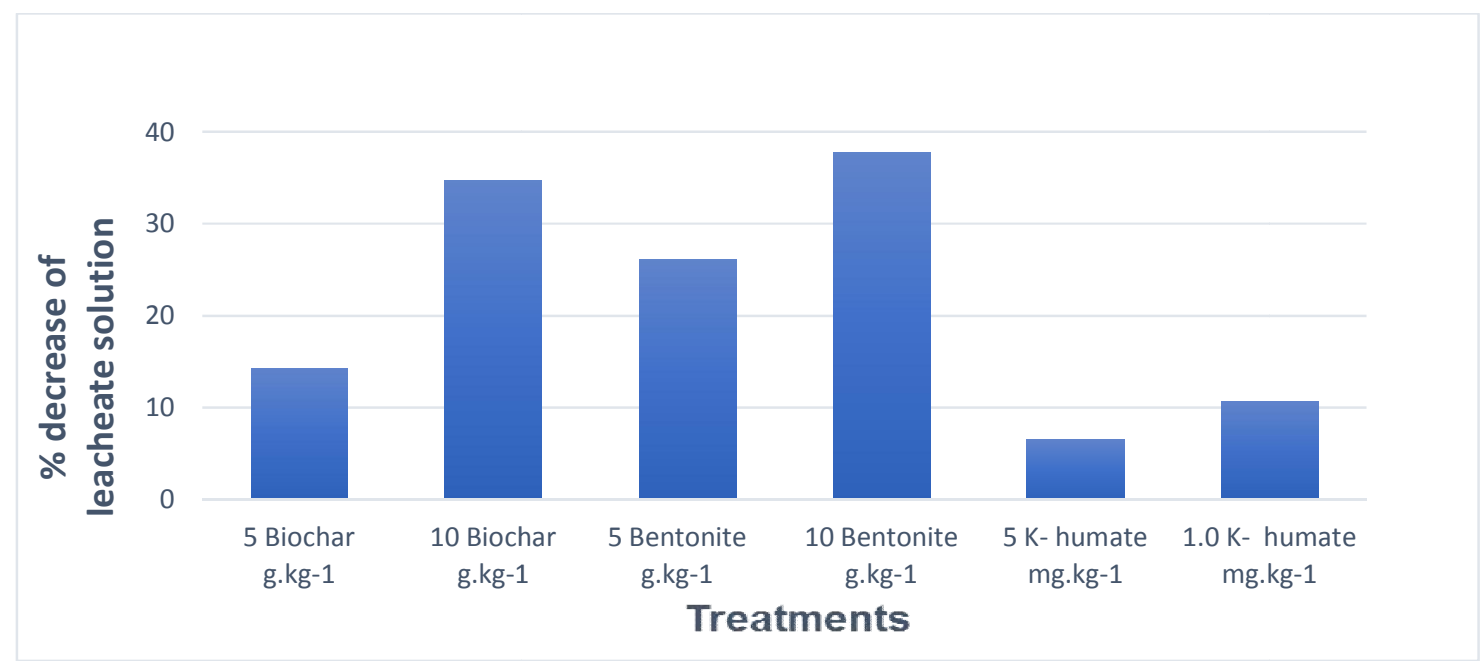

(b)

Fig. 1. Volume of soil leachate solution per liter (a) and \% decrease of leachate solution (b) as affected by the studied materials 
Table 2. Available macronutrients content and nitrogen loss in soil as affected by biochar, bentonite and K- humate after barley harvest

\begin{tabular}{|c|c|c|c|c|c|c|c|}
\hline Treatments & & $\begin{array}{l}\text { Available } \mathrm{N} \text { in } \\
\text { soil } \mathrm{mg} \cdot \mathrm{kg}^{-1}\end{array}$ & $\begin{array}{l}\text { \% increase } \\
\mathrm{N} \text { in soil }\end{array}$ & $\begin{array}{l}\text { Total } \mathrm{N} \text { loss in } \\
\text { leachate solution } \\
\text { mg. } \mathrm{I}^{-1}\end{array}$ & $\begin{array}{l}\% \text { decrease of } \mathrm{N} \text { in } \\
\text { leachate solution }\end{array}$ & $\begin{array}{l}\text { Available } P \text { in } \\
\text { soil } \mathrm{mg} \cdot \mathrm{kg}^{-1}\end{array}$ & $\begin{array}{l}\text { Available } \mathrm{K} \text { in } \\
\text { soil } \mathrm{mg} \cdot \mathrm{kg}^{-1}\end{array}$ \\
\hline Control & & $50.40^{d}$ & - & $24.15^{\mathrm{a}}$ & - & $14.00^{\mathrm{d}}$ & $90.50^{d}$ \\
\hline \multirow[t]{2}{*}{ Biochar g. kg ${ }^{-1}$} & 5 & $61.20^{b}$ & 21.43 & $19.67^{\mathrm{b}}$ & 18.55 & $14.50^{\mathrm{c}}$ & $112.00^{c}$ \\
\hline & 10 & $64.00^{a}$ & 26.98 & $15.44^{\mathrm{c}}$ & 36.07 & $15.20^{\mathrm{b}}$ & $123.50^{\mathrm{b}}$ \\
\hline \multirow[t]{2}{*}{ Bentonite g. $\mathrm{kg}^{-1}$} & 5 & $55.00^{c}$ & 9.13 & $19.80^{\mathrm{b}}$ & 18.01 & $15.65^{\mathrm{b}}$ & $114.00^{c}$ \\
\hline & 10 & $62.00^{b}$ & 23.02 & $15.50^{c}$ & 35.82 & $16.50^{\mathrm{a}}$ & $134.50^{a}$ \\
\hline \multirow[t]{2}{*}{$\mathrm{K}$ - humate $\mathrm{mg} \cdot \mathrm{kg}^{-1}$} & 5 & $53.40^{c}$ & 5.95 & $20.65^{b}$ & 14.49 & $14.00^{d}$ & $110.00^{c}$ \\
\hline & 10 & $56.50^{c}$ & 12.10 & $18.40^{\mathrm{b}}$ & 23.81 & $14.80^{c}$ & $125.00^{\mathrm{b}}$ \\
\hline
\end{tabular}

Table 3. Soil characteristics as affected by biochar, bentonite and potassium humate after barley harvest

\begin{tabular}{|c|c|c|c|c|c|c|c|c|c|}
\hline \multirow[t]{2}{*}{ Treatments } & & \multirow[t]{2}{*}{$\mathrm{pH}$} & EC & \multirow[t]{2}{*}{ TOC g. $\mathbf{k g}^{-1}$} & \multirow{2}{*}{$\begin{array}{l}\text { Bd } \\
M^{-3} \cdot m^{-3}\end{array}$} & \multirow{2}{*}{$\begin{array}{l}\text { Porosity } \\
\%\end{array}$} & \multirow{2}{*}{$\begin{array}{c}\text { FC } \\
\% \\
\end{array}$} & \multirow{2}{*}{\begin{tabular}{|l} 
WP \\
$\%$
\end{tabular}} & \multirow{2}{*}{$\begin{array}{c}\text { AW } \\
\%\end{array}$} \\
\hline & & & dS. $m^{-1}$ & & & & & & \\
\hline Control & & $7.80^{a}$ & $4.90^{\mathrm{a}}$ & $2.32^{b}$ & $1.56^{\mathrm{a}}$ & $41.13^{b}$ & $11.00^{a}$ & $3.80^{a}$ & $7.20^{b}$ \\
\hline \multirow{2}{*}{ Biochar g.kg ${ }^{-1}$} & 5 & $7.83^{a}$ & $4.48^{b}$ & $2.79^{a}$ & $1.51^{\mathrm{a}}$ & $43.02^{a}$ & $11.68^{a}$ & $3.92^{\mathrm{a}}$ & $7.76^{a}$ \\
\hline & 10 & $7.88^{a}$ & $4.30^{b}$ & $3.20^{\mathrm{a}}$ & $1.48^{b}$ & $44.15^{a}$ & $11.90^{\mathrm{a}}$ & $4.00^{\mathrm{a}}$ & $7.90^{\mathrm{a}}$ \\
\hline \multirow[t]{2}{*}{ Bentonite $\mathrm{g} \cdot \mathrm{kg}^{-1}$} & 5 & $7.85^{a}$ & $5.00^{a}$ & $2.62^{\mathrm{a}}$ & $1.55^{\mathrm{a}}$ & $41.51^{a}$ & $11.40^{a}$ & $3.90^{a}$ & $7.50^{a}$ \\
\hline & 10 & $7.90^{a}$ & $5.20^{a}$ & $2.97^{\mathrm{a}}$ & $1.50^{\mathrm{a}}$ & $43.40^{\mathrm{a}}$ & $11.85^{a}$ & $4.00^{a}$ & $7.85^{a}$ \\
\hline \multirow[t]{2}{*}{$\mathrm{K}$ - humate $\mathrm{mg} \cdot \mathrm{kg}^{-1}$} & 5 & $7.77^{a}$ & $4.33^{b}$ & $2.62^{a}$ & $1.53^{a}$ & $42.26^{a}$ & $11.30^{a}$ & $3.88^{a}$ & $7.42^{a}$ \\
\hline & 10 & $7.75^{a}$ & $4.20^{\mathrm{b}}$ & $2.91^{\text {a }}$ & $1.50^{\mathrm{a}}$ & $43.40^{a}$ & $11.38^{a}$ & $3.96^{a}$ & $7.42^{a}$ \\
\hline
\end{tabular}


Abdeen; ARRB, 35(12): 45-55, 2020; Article no.ARRB.63007

Table 4. Barley growth (fresh and dry weight) and macronutrients content and uptake as affected by biochar, bentonite and potassium humate

\begin{tabular}{|c|c|c|c|c|c|c|c|c|c|c|c|}
\hline \multirow[t]{2}{*}{ Treatments } & & \multicolumn{2}{|c|}{$\frac{\text { FW }}{\text { g. column }}$} & \multicolumn{2}{|c|}{$\begin{array}{c}\text { DW } \\
\text { g. column } \\
\end{array}$} & \multicolumn{3}{|c|}{$\begin{array}{c}\text { Content } \\
\%\end{array}$} & \multicolumn{3}{|c|}{$\begin{array}{c}\text { Uptake } \\
\text { mg. column }^{-1}\end{array}$} \\
\hline & & Value & $\%$ increase & Value & $\%$ increase & $\mathbf{N}$ & $\mathbf{P}$ & $\mathrm{K}$ & $\mathbf{N}$ & $\mathbf{P}$ & $\mathrm{K}$ \\
\hline Control & & $47.30^{\mathrm{e}}$ & - & $7.90^{\mathrm{C}}$ & - & $1.43^{\mathrm{C}}$ & $0.30^{b}$ & $1.25^{b}$ & $112.97^{\mathrm{e}}$ & $23.70^{\mathrm{C}}$ & $98.75^{\dagger}$ \\
\hline \multirow[t]{2}{*}{ Biochar g.kg ${ }^{-1}$} & 5 & $56.80^{c}$ & 20.08 & $8.70^{\mathrm{b}}$ & 10.13 & $1.70^{\mathrm{a}}$ & $0.32^{\mathrm{b}}$ & $1.33^{a}$ & $147.90^{c}$ & $27.84^{b}$ & $115.71^{\mathrm{e}}$ \\
\hline & 10 & $67.20^{\mathrm{a}}$ & 42.07 & $9.87^{a}$ & 24.94 & $1.75^{\mathrm{a}}$ & $0.30^{\mathrm{b}}$ & $1.47^{\mathrm{a}}$ & $172.73^{a}$ & $29.61^{b}$ & $145.09^{\mathrm{a}}$ \\
\hline \multirow[t]{2}{*}{ Bentonite g. $\mathrm{kg}^{-1}$} & 5 & $54.30^{d}$ & 14.8 & $8.50^{b}$ & 7.59 & $1.50^{\mathrm{c}}$ & $0.33^{b}$ & $1.40^{a}$ & $127.50^{d}$ & $28.05^{b}$ & $119.00^{c}$ \\
\hline & 10 & $64.25^{\mathrm{b}}$ & 35.84 & $9.50^{a}$ & 20.25 & $1.63^{\mathrm{b}}$ & $0.38^{a}$ & $1.55^{a}$ & $154.85^{b}$ & $36.10^{a}$ & $147.25^{\mathrm{a}}$ \\
\hline K- humate & 5 & $52.50^{d}$ & 10.99 & $8.20^{b}$ & 3.8 & $1.50^{\mathrm{c}}$ & $0.32^{b}$ & $1.36^{a}$ & $123.00^{d}$ & $26.24^{b}$ & $111.52^{d}$ \\
\hline mg.kg ${ }^{-1}$ & 10 & $55.40^{c}$ & 17.12 & $8.50^{a}$ & 7.59 & $1.50^{\mathrm{c}}$ & $0.33^{b}$ & $1.60^{a}$ & $127.50^{d}$ & $28.05^{b}$ & $136.00^{\mathrm{b}}$ \\
\hline
\end{tabular}




\section{CONCLUSION}

From the results cited above, it can be concluded that there is a positive effect of bentonite, biochar and potassium humate on the availability of macronutrients. Biochar and bentonite were more effective for improving nitrogen retention in saline soils. Nitrogen loss decreased significantly by the addition of the highest rates of biochar and bentonite as a result of decreasing leachate volumes and nitrate concentrations in the leachate solution. Organic carbon, soil porosity and available water were increased by increasing the addition rates of bentonite and biochar. The changes in soil properties led to enhancing the uptake of nutrients by barley plant. So, it is recommended to use the highest doses of biochar and bentonite (10 g. $\left.\mathrm{kg}^{-1}\right)$ for improving soil properties and nutrients retention in saline soil, but it must be taken in our consideration the raising of $\mathrm{pH}$ values especially in biochar treatment.

\section{COMPETING INTERESTS}

Author has declared that no competing interests exist.

\section{REFRENCES}

1. Hossain S. Present scenario of global salt affected soils, its management and importance of salinity research. International Research Journal of Biology Sciences. 2019;1 (1):1-3.

2. Kaledhonkar MJ, Meena BL, Sharma PC. Reclamation and nutrient management for salt-affected soils. Indian Journal of Fertilisers. 2019;15(5):566-575.

3. Naveed M, Sajid H, Mustafa A, Niamat B, Ahmad Z, Yaseen M et al. Alleviation of salinity-induced oxidative stress, improvement in growth, physiology and mineral nutrition of canola (Brassica napus L.) through calcium-fortified composted animal manure. Sustainability. 2020;(12) 846:1-17.

4. Russo TA, Tully K, Palm C, Neill C. Leaching losses from Kenyan maize cropland receiving different rates of nitrogen fertilizer. Nutrient Cycling in Agroecosyst. 2017; 108:195-209.

5. Naz MY, Sulaiman SA. Slow release coating remedy for nitrogen loss from conventional urea: A review. J Control Release. 2016; 225:109-120.

6. Wang $Y$, Ying $H$, Yin $Y$, Zheng $H$, Cui $Z$. Estimating soil nitrate leaching of nitrogen fertilizer from global meta-analysis. Sci Total Environ. 2019; 657:96-102.

7. Guilhen SN, Masek O, Ortiz N, Izidoro JC, Fungaro D. A pyrolytic temperature evaluation of macauba biochar for uranium adsorption from aqueous solutions. J Biomass and Bioenergy. 2019;122: 381390.

8. Nguyen VT, Nguyen TB, Chen CW, Hung $\mathrm{CM}$, Vo TDH, Chang JH et al. Influence of pyrolysis temperature on polycyclic aromatic hydrocarbons production and tetracycline adsorption behavior of biochar derived from spent coffee ground. Bioresource Technol. 2019; 284:197-203.

9. Tomczyk A, Sokołowska Z, Boguta P. Biochar physicochemical properties: Pyrolysis temperature and feedstock kind effects. Rev. Environmental Sci. Biotechnology. 2020; 19:191-215.

10. Huang LQ, Fu C, Li TZ, Yan B, Wu Y, Zhang L. Advances in research on effects of biochar on soil nitrogen and phosphorus. Earth and Environmental Science. 2020; 424:1-8.

11. Cheng JZ, Li YL, Gao WC, Chen Y, Pan WJ, Lee $X Q$ et al. Effects of biochar on cd and $\mathrm{pb}$ mobility and microbial community composition in a calcareous soil planted with tobacco. Biol Fertile Soils. 2018; 54:373-383.

12. Shui-qin Z, Liang $Y$, Wei L, Zhi-An L, YanTing L, Shu-Wen $H$. Effects of urea enhanced with different weathered coalderived humic acid components on maize yield and fate of fertilizer nitrogen. Journal of Integrative Agriculture. 2019;18(3):656666.

13. Tan $\mathrm{KH}$. Humic matter in soil and the environment: Principles and controversies. CRC Press, USA; 2014.

14. El-Etr WMT, Hassan WZ. Effect of potassium humate and bentonite on some soil chemical properties under different rates of nitrogen fertilization. J Soil Sci and Agric. Eng, Mansoura Univ. 2017;8(10):539 - 544.

15. Kayama M, Nimpila $S$, Hongthong $S$, Yoneda R, Wichiennopparat W, Himmapan W et al. Effects of bentonite, charcoal and corncob for soil Improvement and growth characteristics of teak seedling planted on Acrisols in Northeast Thailand. Forests. 2016; 7(36):1-21.

16. Zhang $\mathrm{H}$, Chen W, Zhao B, Phillips LA, Zhou Y, Lapen DR et al. Sandy soils amended with bentonite induced changes 
in soil microbiota and fungi stasis in maize fields. Applied Soil Ecology. 2020; 146:112.

17. Mohawesh O, Durner W. E $\square$ ects of bentonite, hydrogel and biochar amendments on soil hydraulic properties from saturation to oven dryness. Pedosphere. 2019;29(5):598-607.

18. Gee GW, Bauder JW, A Klute. Particlesize Analysis Methods of Soil Analysis. Part 1. 2nd Agron. Monogr. 9. ASA and SSSA, Madison, WI. 1986;383-411.

19. Grossman RB, Reinsch TG, Dane JH, Topp, GC. Bulk density and linear extensibility: Core method. Methods of Soil Analysis. Part 4, Physical Methods, SSSA, Incorporated, Madison. 2002;208-228.

20. Thomas GW. Soil $\mathrm{pH}$ and Soil Acidity. Methods of Soil Analysis part 3. Chemical Methods (Eds DL Sparks. et al.). American Society of Agronomy: Madison, WI.1996;475-490.

21. Summer ME, Miller WP, Sparks DL. Cation Exchange Capacity and Exchange Coefficients Methods of Soil Analyses part 3 Chemical methods. Madison: Soil Science Society of America Inc. 1996; 1201-1229.

22. Dellavalle NB. Determination of specific conductance in supernatant 1:2 Soil: Water solution in handbook on reference methods for soil analysis. Soil and Plant Analysis Council. 1992;44-50.

23. Nelson DW, Sommers LE. Methods of Soil Analysis. part 3. Chemical Methods. Soil Science Society of America Book Series. 1996; 5:961-1010.

24. Mohsen S, Rashidi M, Khabbaz B Gh. Prediction of soil exchangeable sodium percentage based on soil sodium adsorption ratio. American-Eurasian $\mathrm{J}$ Agric and Environ Sci., 2009;5(1):1-4.

25. US. Salinity laboratory staff. diagnosis and improvement of saline and alkali soils. US Dept. agriculture, handbook 60. U.S. Government Printing Office, Washington. 1954;160.

26. AOAC. Association of Official Agricultural Chemists. Association of Official Analysis Chemists Official Methods of Analysis. 15th ed. Washington, DC, USA; 1995.

27. Levesque R. SPSS programming and data management: A guide for SPSS and SAS users. $4^{\text {th }}$ ed. SPSS Inc, Chicago, IL; 2007.

28. Mukherjee A, Zimmerman A, Harris W. Surface chemistry variations among a series of laboratory-produced biochars. Geoderma. 2011; 163:247-255.

29. Gai X, Wang H, Liu J, Zhai L, Liu S, Ren T, Liu $H$. Effects of feedstock and pyrolysis temperature on biochar adsorption of ammonium and nitrate. Plos One. 2014; 9(12):1-19.

30. Bista $P$, Ghimire $R$, Machado $S$, Pritchett $\mathrm{L}$. Biochar e $\square$ ects on soil properties and wheat biomass vary with fertility management. Agronomy .2019; 9(623):110.

31. Lehmann J. A handful of carbon, Nature. 2007; 447:143-144.

32. Du J, Sun $P$, Feng $Z$, Zhang $X$, Zhao $Y$. The biosorption capacity of biochar for 4bromodiphengl ether: Study of its kinetics, mechanism, and use as a carrier for immobilized bacteria. Environ Sci Pollut R. 2019; 23:3770-3780.

33. Guo M, Zhang T, Li J, Li Z, Xu G, Yang R. Reducing nitrogen and phosphorus losses from di $\square$ erent crop types in the water source area of the danjiang river, China. Int J Environ Res. Public Health. 2019; 344 (16):1-17.

34. Agafonov EV, Khovanskii MV. Effect of bentonite on the fertility of an ordinary chernozem. Eurasian Soil Science. 2014;47(5):478-482.

35. El-Naggar A, Lee $\mathrm{MH}$, Hur J, Lee $\mathrm{YH}$, Igalavithana $A D$, Shaheen $S M$ et al. Biochar-induced metal immobilization and soil biogeochemical process: An integrated mechanistic approach. Science of the Total Environment. 2020;698,1-11.

36. Cao CT, Farrell C, Kristiansen PE, Rayner JP. Biochar makes green roof substrates lighter and improves water supply to plants. Ecological Engineering. 2014; 71:368-374.

37. Paiman P, Effendy I. The effect of soil water content and biochar on rice cultivation in polybag. Open Agriculture. 2020; 5:117-125.

38. Aydin A, Kant C, Turan M. Humic acid applications alleviate salinity stress of bean (Phaseolus vulgaris L.) plants decreasing membrane leakage. Afr J Agric Research. 2012; 7:1073-1086.

39. Ouni Y, Ghnaya T, Montemurro F, Abdelly C, Lakhdar A. The role of humic substances in mitigating the harmful effects of soil salinity and improve plant productivity. Int J Plant Production. 2014; 8:353-374. 
40. Mahmoud E, El-Beshbeshy T, Abd ElKader N, El- Shal R, Khalafallah N. Impacts of biochar application on soil fertility, plant nutrients uptake and maize (Zea mays L.) yield in saline sodic soil. Arabian Journal of Geosciences. 2019;12 (719):1-9.

41. Czaban J, Siebielec G. Effects of bentonite on sandy soil chemistry in a long-term plot experiment (II); Effect on $\mathrm{pH}, \mathrm{CEC}$ and macro- and micronutrients. Polish Journal of Environmental Studies. 2013; 6 (22): 1669-1676.

42. Khaled H, Fawy HA. Effect of different levels of humic acids on the nutrient content, plant growth, and soil properties under conditions of salinity. Soil and Water Reserch. 2011; 6:21-29.

43. Bassouny MA, Abbas MHH. Role of biochar in managing the irrigation water requirements of maize plants: The pyramid model signifying the soil hydro-physical and environmental markers. Egypt J Soil Sci. 2019; 59(2):99-115.

44. Novak JM, Busscher WJ, Watts DW, Amonette J E, Ippolito JA, Lima IM, and Rehrah D. Biochar's impact on soil-moisture storage in an ultisol and two aridisols. Soil Science. 2012;177(5):310320.

45. Lashari MS, Liu Y, Li L, Pan W, Fu J, Pan $G$ et al. Effects of amendment of biocharmanure compost in conjunction with pyroligneous solution on soil quality and wheat yield of a salt-stressed cropland from Central China Great Plain. Field Crop Reserch. 2013; 144:113-118.

46. Kraska P, Oleszczuk P, Andruszczak S, Kwiecinska-Poppe E, Rozyło K, Pałys E et al. Effect of various biochar rates on winter rye yield and the concentration of available nutrients in the soil. Plant Soil and Environment. 2016; 11:483489.

47. Chan KY, Van Zwieten L, Meszaros I, Downie A, Joseph S. Using poultry litter biochars as soil amendments. Australian Journal of Soil Research. 2008; 46: 437444.

48. Abd- All AH, El-Namas AE, El-Naggar EM. Effect of humic acid and foliar application of different potassium sources on yield, quality and water use efficiency of sweet potato grown under drip irrigation in sandy soil. Alex Sci Exchange Journal. 2017; 38 (3): 543-552.

(c) 2020 Abdeen; This is an Open Access article distributed under the terms of the Creative Commons Attribution License (http://creativecommons.org/licenses/by/4.0), which permits unrestricted use, distribution, and reproduction in any medium, provided the original work is properly cited.

Peer-review history:

The peer review history for this paper can be accessed here: http://www.sdiarticle4.com/review-history/63007 